\title{
Bentuk dan Makna Ritual Mappacci pada Pernikahan Bangsawan Bugis (Studi Kasus di Desa Benteng Gantarang Kabupaten Bulukumba)
}

\author{
Kasmawati ${ }^{1}$ \\ Indarwati ${ }^{2}$ \\ Haryeni $^{3}$ \\ Hasan $^{4}$
}

\section{Universitas Muslim Maros, Politeknik LP3I Makassar; ${ }^{2,3}$ Universitas Hasanuddin}

1kasma89@umma.ac.id

2indarwatipolinas@gmail.com

3haryeni@unhas.ac.id

${ }^{4}$ hasanali.unhas23@gmail.com

\begin{abstract}
Abstrak
Mapacci adalah salah satu dari sekian banyak ritual dalam pernikahan adat suku Bugis di Sulawesi Selatan. Ritual ini adalah upacara untuk membersihkan dan menyucikan diri bagi calon pengantin dari hal-hal yang tidak baik. Prosesi ini biasa dilaksanakan pada saat menjelang acara akad nikah keesokan harinya. Adat kebudayaan ini ditradisikan oleh masyarakat dan diyakini dapat membawa keberkahan dalam pernikahan hingga sampai sekarang. Penelitian ini difokuskan pada bentuk makna dalam ritual upacara adat mappacci. Jenis penelitian ini merupakan penelitian kualitatif bertema budaya lokal. Data dikumpulkan dengan metode observasi, dengan teknik rekam, catat, dan wawancara. Data yang terkumpul kemudian dianalisis dengan menggunakan analisis secara deskriptifkualitatif. Hasil penelitian menunjukkan bahwa ada beberapa makna ritual dalam ritual mapacci pada pernikahan bangsawan Bugis di desa Benteng Gantarang kabupaten Bulukumba, yakni: kesucian hati calon mempelai menghadapi hari esok; harapan, yang dimaknai semoga pernikahan nanti akan berlangsung dengan langgeng (selamanya); doa dan restu dari para keluarga; makna agar calon mempelai kelak di kemudian hari dapat hidup bahagia seperti mereka yang meletakkan pacci di atas tangannya.
\end{abstract}

Kata kunci: Bentuk, Makna, Ritual Mappaci, Bugis

\section{Abstract}

Mapacci is one of the many rituals in the traditional wedding of the Bugis tribe in South Sulawesi. This ritual is a ceremony to cleanse and purify the bride and groom from things that are not good. This procession is usually carried out before the wedding ceremony the next day. This cultural custom has been traditionalized by the community and is believed to be able to bring blessings in marriage until now. This research is focused on the form of meaning in the traditional mappacci ceremonial ritual. This type of research is a qualitative research with the theme of local culture. Data were collected by observation method, with recording, note-taking, and interview techniques. The collected data was then analyzed using descriptive-qualitative analysis. The results showed that there were several ritual meanings in the mapacci ritual at the wedding of Bugis nobles in Benteng Gantarang village, Bulukumba district, namely: the purity of the heart of the prospective bride and 
groom facing tomorrow; hope, which means that the marriage will last forever (forever); the prayers and blessings of the families; meaning that the future bride and groom can live happily like those who put pacci on their hands.

Keywords: Form, Meaning, Mappaci Ritual, Bugis

\section{Pendahuluan}

Kebudayaan merupakan persoalan yang sangat komplek dan luas, misalnya kebudayaan yang berkaitan dengan cara manusia hidup, adat istiadat dan tata krama. Masyarakat Indonesia adalah masyarakat majemuk yang memiliki bermacam-macam kebudayaan dan adat-istiadat yang hidup dalam kesatuan sosial. Masyarakat Indonesia yang juga heterogen, termasuk adat istiadat dan kebiasaannya yang berbeda dan masih dipertahankan sampai saat ini, termasuk adat perkawinan.

Budaya seperti juga komunikasi adalah istilah yang sudah akrab bagi kebanyakan orang. Sebagai bagian dari keakraban ini, istilah budaya digunakan dengan cara yang berbeda-beda. Penggunaan yang paling umum dari istilah budaya adalah sebagai persamaan kata dari negeri atau bangsa. Jika berkelana melintas, beberapa masyarakat yang menggunakan bahasa bukan Inggris, atau mendapati seorang perempuan yang mengenakan cincin di wajahnya, dapat dikatakan bahwa mereka berasal dari budaya berbeda, yang artinya dalam kasus ini, bahwa mereka berasal dari negeri yang berbeda. (Nur, E., \& Pala, R., 2020).

Secara umum, kita dapat memahami bahwa kearifan lokal adalah pengetahuan yang dikembangkan oleh para leluhur dalam mensiasati lingkungan hidup sekitar mereka, menjadikan pengetahuan itu sebagai bagian dari budaya dan memperkenalkan serta meneruskan itu dari generasi ke generasi. Beberapa bentuk pengetahuan tradisional itu muncul lewat cerita-cerita, legenda-legenda, nyanyian-nyanyian, ritual-ritual, dan juga aturan atau hukum setempat.

Budaya lokal akan lebih bermakna karena mampu mendorong semangat kecintaan pada kehidupan manusia dan alam semesta. Sementara teknologi sebagai hasil kebudayaan yang bersifat fisik tanpa spritualitas nilai-nilai yang terkandung dalam adat istiadat, agama, kesenian akan kehilangan fungsi untuk meningkatkan kualitas hidup manusia. Nilai-nilai, norma, etika yang terkandung dalam aturan adat tercermin dalam budaya lokal semestinya merupakan referensi-referensi yang bermanfaat di era global (Budi Setyaningrum, 2018).

Suku Bugis merupakan salah satu suku yang masih mempertahankan budaya dan adat-istiadatnya di Indonesia, khususnya di Sulawesi Selatan. Dalam kehidupan masyarakat Bugis, hubungan kekerabatan merupakan aspek utama. Baik dinilai penting oleh anggota masyarakatnya, maupun fungsinya sebagai suatu struktur dasar dalam suatu tatanan masyarakat. Pengetahuan mendalam tentang prinsip-prinsip kekerabatan sangat penting bagi orang Bugis untuk membentuk tatanan sosial mereka.

Aspek kekerabatan tersebut termasuk dalam upacara pernikahan atau perkawinan. Oleh karena dianggap sebagai pengantar kelakuan manusia yang bersangkut paut dengan kehidupan rumah tangganya. Perkawainan dalam adat budaya suku Bugis merupakan salah satu bagian terpenting dalam kehidupan manusia. Suatu perkawinan tidak hanya merupakan peristiwa yang dialami oleh dua orang individu berlainan jenis, melainkan juga melibatkan berbagai pihak. Baik itu kerabat keluarga maupun kedua mempelai lebih dalam lagi. Pernikahan melibatkan kesaksian dari anggota masyarakat, 
melalui upacara perkawinan yang dianggap sebagai pangkuan masyarakat terhadap bersatunya dua orang individu dalam ikatan yang sacral, yakni pernikahan atau perkawinan.

Mappacci merupakan salah satu rangkaian upacara adat perkawinan yang turuntemurun dilakukan oleh masyarakat suku Bugis di Sulawesi Selatan. Upacara adat ini bertujuan untuk membersihkan atau menyucikan calon mempelai dari hal-hal yang buruk. Masyarakat melestarikan tradisi ini dengan keyakinan bahwa tujuan yang baik harus didasari oleh niat dan upaya yang baik pula. Upacara mappacci atau sebagian orang menyebutnya mappaccing, memiliki asal kata dari "paccing" yang berarti bersih. Ritual ini bertujuan membersihkan diri calon pengantin dari semua hal yang mungkin akan muncul sebagai hambatan dalam pelaksanaan pernikahan. Mappacci juga bisa diartikan dari kata "pacci" yang artinya daun pacar. Oleh karena itu, dalam prosesi ini, calon pengantin akan dipasangkan daun pacar di tangannya sambil didoakan.

Upacara adat mappacci ini merupakan sebuah rangkaian perayaan pesta pernikahan di kalangan masyarakat Bugis yang masih kental dengan adat istiadatnya. Ritual upacara yang juga memiliki pengertian pensucian diri, sekaligus sebagai wahana pewarisan nilai-nilai kesucian bagi calon pengantin. Pada prosesi ini, kadang-kadang penggunaan simbol memiliki sarat makna yang butuh pemahaman mendalam guna memahaminya. Mappacci yang dimaksudkan membersihkan segala sesuatu dan mensucikan diri dari hal yang tidak baik, juga melambangkan kesucian hati calon pengantin menghadapi hari esok, khususnya memasuki bahtera rumah tangga.

\section{Kerangka Teori}

Sesuai dengan etimologisnya, upacara ritual dapat dibagi atas dua kata, yakni upacara dan ritual. Upacara adalah suatu kegiatan yang dilaksanakan sekelompok orang serta memiliki tahapan yang sudah diatur sesuai dengan tujuan acara. Sedangkan yang dimaksud dengan ritual adalah suatu hal yang berhubungan terhadap keyakinan dan kepercayaan spritual dengan suatu tujuan tertentu. Ritual atau ritus dilakukan dengan tujuan untuk mendapatkan berkah, seperti upacara dalam kehidupan manusia, yakni pernikahan.

Ritual merupakan salah satu cara dalam berkomunikasi. Semua bentuk ritual adalah komunikasi. Ritual selalu merupakan perilaku simbolik dalam situasi-situasi sosial. Oleh karena itu, ritual merupakan salah satu cara untuk menyampaikan sesuatu (Manafe, 2011).

Berdasarkan uraian di atas, dapat dilihat ritual upacara mappacci merupakan suatu upacara adat yang dilakukan oleh masyarakat setempat dengan menggunakan alatalat tertentu, tempat, dan cara-cara tertentu pula. Namun, dalam ritual mappacci ini mempunyai fungsi yang sama, yaitu untuk berdoa seperti Al-barzanji, khotaman Alqur'an yang tujuannya untuk mendapatkan berkah bagi pasangan calon pegantin tersebut.

Teori yang digunakan dalam kajian atau penelitian ini adalah teori strukturalisme dan semiotik budaya. Kebudayaan adalah sebuah sistem tanda yang memiliki beberapa peranan, di antaranya cara pemahaman, perhubungan, dan penciptaan. Objek kebudayaan adalah segala yang ada dan dihasilkan daam masyararakat dan unsur-unsur pembentuk kebudayaan. Kebudayaan juga merupakan sistem yang berupa gagasan, kelakuan, dan hasil kelakuan. Dengan kata lain, kebudayaan adalah hasil cipta, rasa, dan karsa manusia. Kebudayaan suatu etnik merupakan instrumen atau alat dalam kehidupan 
masyarakatnya dengan nilai-nilai yang terkandung dalam kebudayaannya menjadi patokan sekaligus menjadi tujuan hidupnya. Pada sisi yang sama, masyarakat sebagai pelaku kebudayaan kurang menumbuhkan rasa tanggung jawab diri sebagai pewaris tradisi (Mattulada, 1985).

Lahirnya semiotika tidak dapat dilepaskan dari bayangan strukturalisme yang mendahuluinya, dalam perkembangan ilmu pengetahuan budaya. Perkembangan dari strukturalis ke semiotik dapat dibagi dua, yakni yang sifatnya melanjutkan sehingga ciriciri strukturalismenya masih sangat kelihatan dan yang sifatnya mulai meninggalkan sifat strukturalisme untuk lebih menonjolkan kebudayaan sebagai sistem tanda.

Teeuw, A. (1984), mendefinisikan semiotik adalah tanda sebagai tindak komunikasi dan kemudian disempurnakannya menjadi model sastra yang mempertanggungjawabkan semua faktor dan aspek hakiki untuk pemahaman gejala susastra sebagai alat komunikasi yang khas di dalam masyarakat mana pun. Semiotik merupakan cabang ilmu yang relatif masih baru, penggunaan tanda dan semua yang mengenai tanda dipelajari secara lebih terstruktur dalam bidang semiotik pada abad kedua puluh kemudian berkembang hingga sekarang ini.

Semiotika adalah studi tentang tanda dan segala yang berhubungan dengannya seperti cara berfungsinya, hubungannya dengan tanda-tanda lain, pengirimnya dan penerimaannya oleh mereka yang menggunakannya. Semiotika juga merupakan ilmu yang mengkaji tentang tanda dalam kehidupan manusia. Artinya, semua yang hadir dalam kehidupan kita dilihat sebagai tanda yaitu sesuatu yang harus kita beri makna (Hoed, 2008).

Semiotika adalah ilmu yang mengkaji tanda dalam kehidupan manusia. Artinya semua yang hadir dalam kehidupan kita dilihat sebagai tanda, yakni sesuatu yang harus kita beri makna. Para strukturalis, merujuk pada Ferdinand de Saussure dalam (Hoed, 2008), melihat tanda sebagai pertemuan antara bentuk (yang tercitra dalam kognisi seseorang) dan makna (atau isi, yakni yang dipahami oleh manusia pemakai tanda).

De Saussure dalam (Hoed, 2008) menggunakan istilah penanda (significant) untuk segi bentuk suatu tanda, dan pertanda (signife) untuk segi maknanya. Ferdinand de Saussure adalah bapak linguistik asal perancis, mengemukakan teori tentang tanda linguistik (perancis : signe linguistique). Menurut Ferdinand de Saussure setiap tanda linguistik terdiri dari dua unsur, yaitu (1) yang diartikan (Perancis : signifie', Inggris : signified) dan (2) yang mengartikan Perancis : significant, Inggris : signifier). Yang artinya (signifie', signified) sebenarnya tidak lain dari pada konsep atau makna dari sesuatu tanda bunyi. Sedangkan yang mengartikan (signifiant atau signifier) adalah tidak lain dari bunyibunyi itu, yang terbentuk dari fonem-fonem bahasa yang bersangkuktan. Jadi, dengan kata lain setiap tanda linguistik terdiri dari unsur bunyi dan unsur makna. Kedua unsur ini adalah unsur dalam bahasa (intralingual) yang biasanya merujuk/mengacu kepada sesuatu yang referen yang merupakan unsur luar bahasa (ekstralingual).

De Saussure dalam (Hoed, 2008) juga mengajukan konsep signé (tanda) untuk menunjukkan hubungan antara signifié (yang ditandai) dan significant (yang menandai). Signifié adalah makna atau konsep dari signifiant yang berwujud bunyi-bunyi bahasa. Signifié dan signifiant sebagai signé linguistique adalah satu kesatuan yang merujuk pada satu referen yaitu sesuatu, berupa benda atau hal yang diluar bahasa.

Pengertian makna dalam sense dibedakan dari (meaning-bahasa Inggris) di dalam semantik. Menurut Kridalaksana (1993), bahwa makna merupakan maksud pembicaraan, pengaruh suatu bahasa dalam pemahaman resepsi atau prilaku manusia, hubungan dalam arti kepadanan antara bahasa dan luar bahasa atau antara ujaran dan semua lambang yang ditujukannya, dan cara menggunakan lambang-lambang bahasa. 
Makna sebuah kalimat sering kali tidak bergantung pada sistem gramatikal dan leksikal saja, tetapi bergantung pada kaidah wacana. Makna sebuah kalimat yang baik pilihan katanya dan susunan gramatikalnya sering tidak dapat dipahami tanpa memperhatikan hubungannya dengan kalimat lain dalam sebuah wacana. Pada hakikatnya, mempelajari makna berarti mempelajari pemakaian bahasa dalam suatu masyarakat. Makna bahasa dalam suatu masyarakat dipengaruhi oleh pandangan hidup dan sikap anggota masyarakat yang bersangkutan. Menurut (Indarwati et al., 2020), makna dari makna (meaning) merupakan gabungan semiotik dari sisi teoritis maupun terminologi. Makna akan digunakan dalam pengertian yang luas, yang mencakup dua dimensi arti (atau isi) dan acuan (objek atau denotatum).

\section{Metode Penelitian}

Menurut Sugiyono (2019), metode penelitian merupakan cara ilmiah untuk mendapatkan data dengan tujuan dan kegunaan tertentu. Terdapat empat kata kunci yang mesti diperhatika, yakni: cara ilmiah, data, tujuan, dan kegunaan tertentu. Cara ilmiah berarti kegiatan penelitian didasarkan pada ciri-ciri keilmuan, yaitu rasional, empiris, dan sistematis. Data yang diperoleh dalam penelitian merupakan data empiris, yang valid, reliable, dan objektif.

Penelitian ini difokuskan pada bentuk makna dalam ritual upacara adat mappacci. Jenis penelitian ini merupakan penelitian kualitatif bertema budaya lokal. Data dikumpulkan dengan metode observasi, dengan teknik simak, rekam, catat, dan wawancara. Observasi dilakukan untuk mendengarkan tuturan yang dituturkan oleh pelaksana ritual pada pada saat ritual mappacci berlangsung. Pengamatan langsung ini sangat diperlukan mengingat data yang dibutuhkan berupa pada saat ritual berlangsung. Menurut Nasution (2016), observasi sebagai metode pengumpul data harus sistematis. Artinya, observasi serta pencatatannya dilakukan menurut prosedur dan aturan-aturan tertentu sehingga dapat diulangi kembali oleh peneliti yang lain.

Data primer penelitian ini berupa hasil rekaman dan pencatatan pada saat upacara ritual mappacci. Adapun data sekunder penelitian merupakan hasil wawancara terhadap informan. Data yang terkumpul kemudian dianalisis dengan menggunakan analisis secara deskriptif-kualitatif. Analisis data dilakukan dengan mengorganisasi data, menjabarkannya ke dalam unit-unit, melakukan sintesa, menyusun ke dalam pola, memilih mana yang penting dan yang akan dipelajari, kemudian dibuat kesimpulan.

\section{Hasil dan Pembahasan}

Mappacci adalah kata kerja dari mapaccing yang berarti bersih atau suci. Terkadang, dibeberapa daerah Bugis, mappacci dikenal dengan sebutan mappepaccing. Dalam bahasa Bugis mappacci/mappepacing merupakan rangkaian suatu kegiatan atau aktifitas yang bertujuan untuk membersihkan segala sesuatu. Kata mapacing atau mappacci merupakan dua kata yang berbeda. Yang pertama merupakan kata sifat dan yang kedua kata kerja. Kita sering mendengarkan penggunaan kedua kata ini dalam kehidupan sehari-hari khususnya di masyarakat Bugis (Andi Youshand dalam (Sarpinah, Salimin, 2018).

Apabila keturunan bangsawan melakukan ritual upacara mappacci, mereka akan menyiapkan sembilan perlengkapan, di antaranya: bantal, sarung sutera, daun pucuk pisang, daun nangka, daun pacci, beras melati, lilin, wadah pacci, dan gula merah, tetapi ada perbedaan penggunaan perlengkapan di kalangan bangsawan dengan masyarakat biasa yakni penyediaan sarung sutera, di kalangan masyarakat yang bukan 
keturunan bangsawan menyediakan tujuh lembar sarung sutera sedangkan yang berketurunan bangsawan menyediakan sembilan lembar sarung sutera.

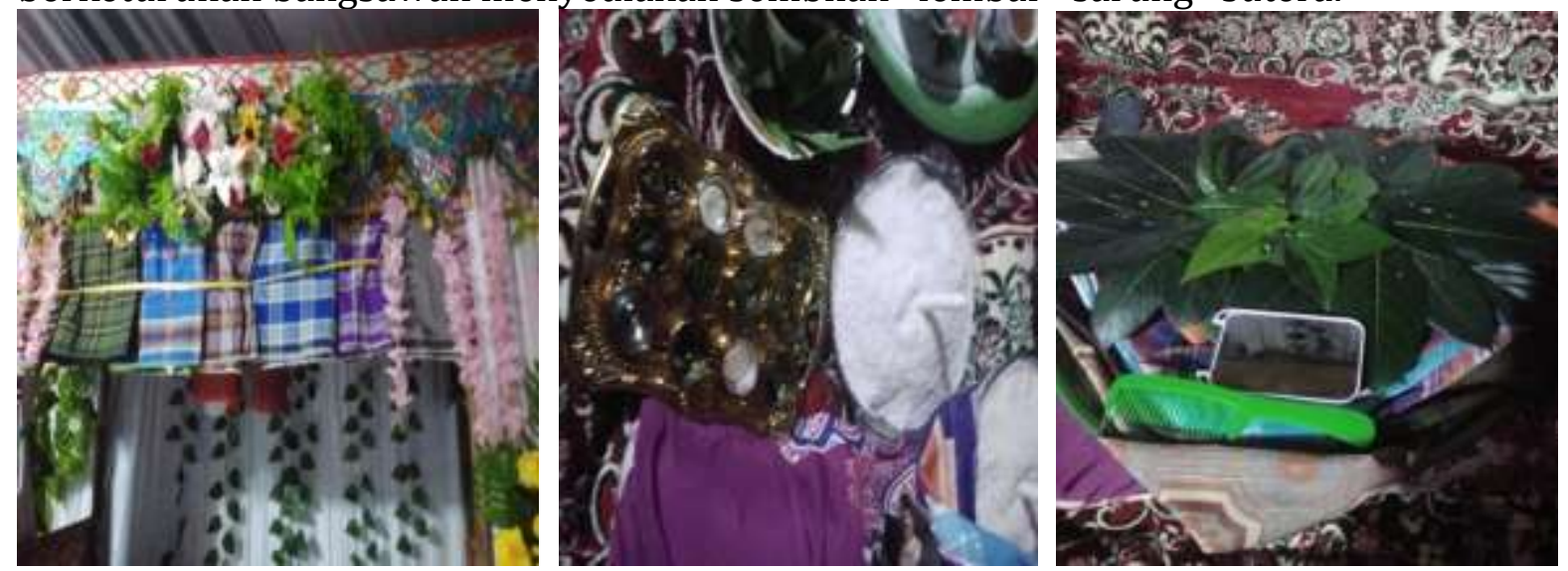

Gambar 1. Beberapa peralatan mappacci

Adapun prosesi upacara ritual mappacci adalah sebagai berikut.

\section{Khatammal Al-Qur'an atau Panre'temme'}

Pernikahan bertujuan medirikan keluarga yang harmonis, sejahtera, dan bahagia. Harmonis, a r t in y a adanya pemenuhan hak dan kewajiban seluruh anggota keluarga. Sejahtera, artinya terciptanya ketenangan lahir dan batin disebabkan terpenuhinya keperluan hidup sehingga timbulah kebahagiaan, yakni rasa kasih sayang antara s eluruh anggota keluarga. Hal ini sejalan dengan firman Allah SWT. Yang berbunyi dalam QS Ar-Rum,. Terjemahannya: Dan di antara ayat-ayat-Nya ialah Dia menciptakan untukmu istri-istri dari jenismu sendiri, supaya kamu merasa nyaman kepadanya, dan dijadikan-Nya di antaramu mawadah dan rahmah. Sesungguhnya pada yang demikian itu benar-benar terdapat tanda-tanda bagi kaum yang berpikir. Khatammal Al-Qur'an diselenggarakan bagi calon mempelai laki-laki dan calon mempelai perempuan dari tempat terpisah.

Dalam ritual ini, wajib didahului pembacaan ayat-ayat suci Al-Qur'an yang dituntun oleh seorang imam/guru. Ritual Panre'temme memiliki makna pesan untuk mengingat kembali ayat suci Al-Qur'an dan senatiasa diridhai Allah. Pembacaan ayat suci Al-Qur'an bagi calon mempelai, diwajibkan terlihat dua buah Al-Qur'an satu untuk dibacakan oleh seorang imam dan yang satu untuk calon pengantin.
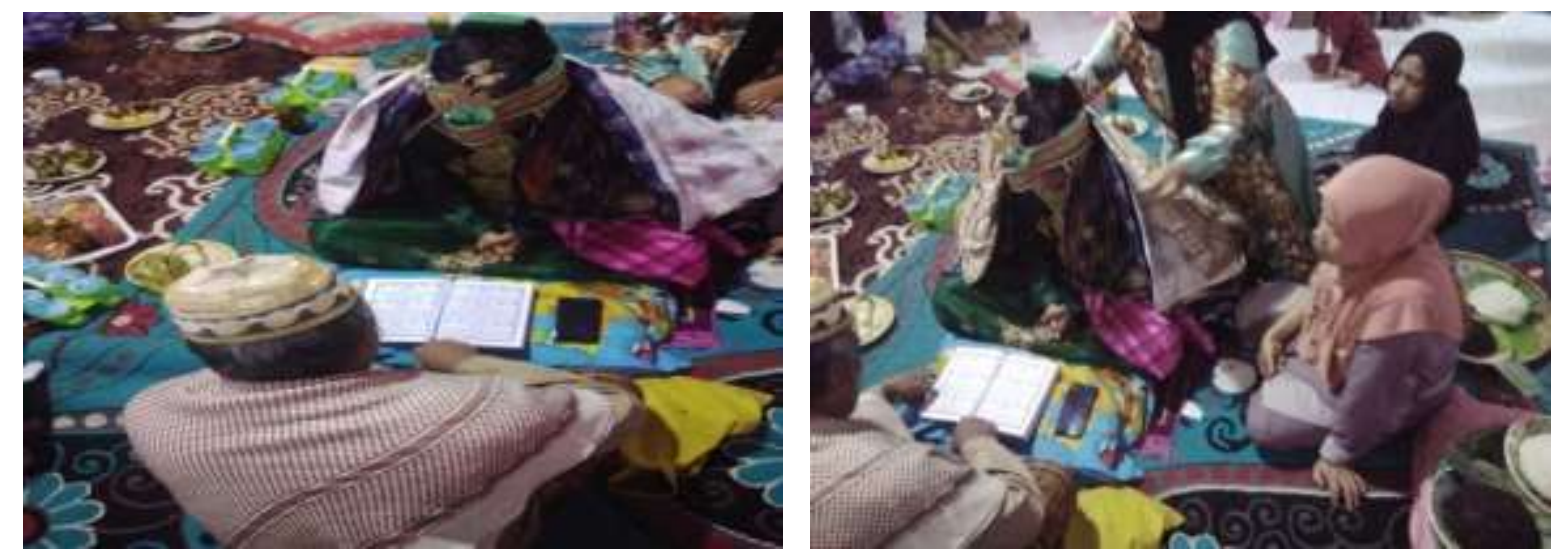

Gambar 2. Khatammal Al-Qur'an atau Panre'temme'

\section{Barazanji}

Setelah khatammal Al-Qur'an selesai dilaksanakan kemudian dilanjutkan dengan barazanji, yang memiliki makna pesan semoga kita senatiasa mengingat dari sanjungan 
kepada kecintaan terhadap Nabi Muhammad atas nikmat Islam. Barazanji ini dilakukan oleh sekumpulan orang-orang yang mengerti akan bacaan barzhanji, yakni bacaan bernada lagu-lagu yang berisi shalawat dan pujian kepada nabi Muhammad. Bacaan ini dibacakan dengan suara keras dan lantang oleh sekumpulan orang-orang muslim dan dipimpin oleh seorang guru/imam.

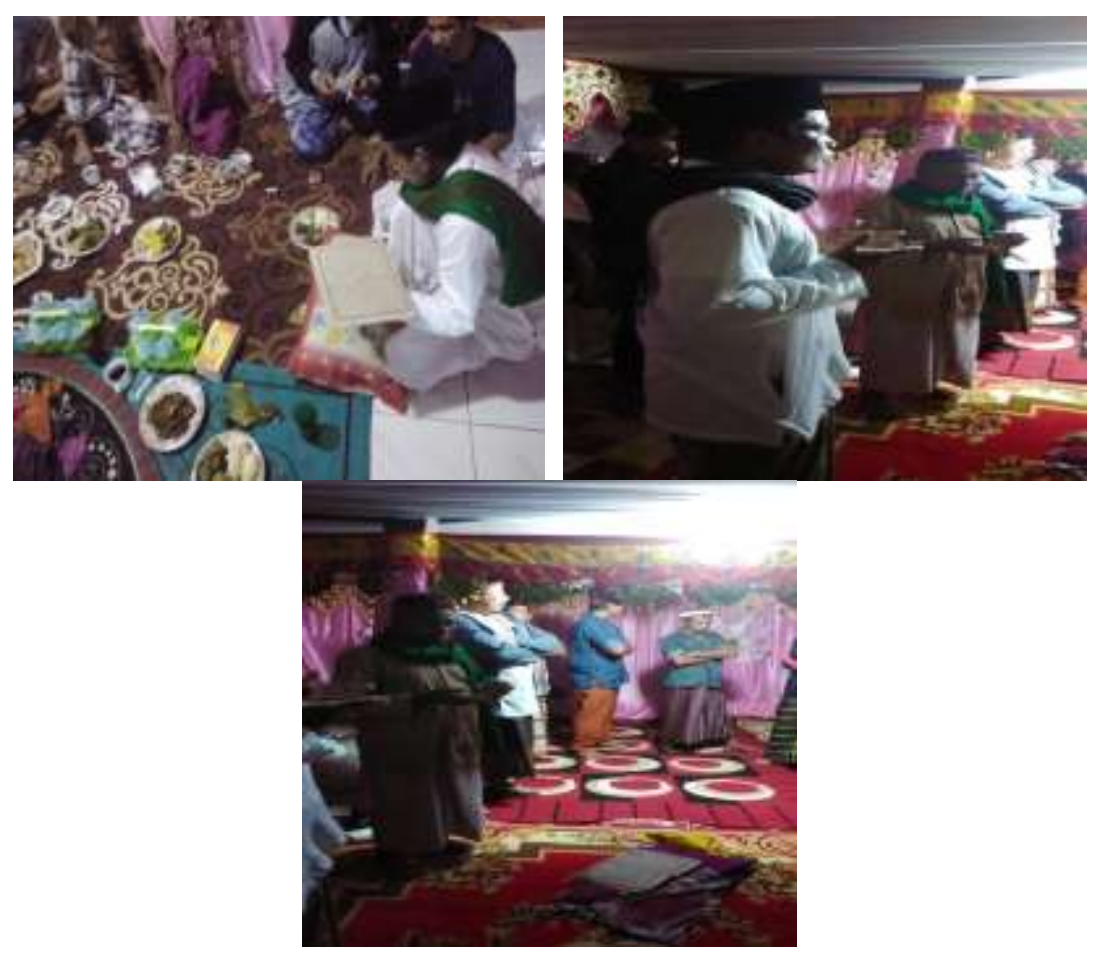

Gambar 3. Barazanji

\section{Mappacci}

Setelah khatammal Al-Qur'an dan barasanji dilaksanakan, barulah memasuki inti dari semua prosesi yaitu, mappacci. Ritual mappacci dilakukan dengan cara meletakkan daun pacci di telapak tangan calon mempelai. Mappacci dilakukan pada malam hari sebelum akad nikah esok harinya, yang berisi pesan untuk membersihkan raga dan kesucian jiwa sebelum memasuki bahtera rumah tangga. Jumlah orang meletakkan pacci ketangan calon mempelai atau orang yang mappacci adalah disesuaikan dengan stratifikasi sosial calon mempelai itu sendiri, 2x7 atau 2x9 keluarga ayah dan ibu harus seimbang, jangan sampai menimbulkan perasaan dengki, iri dan pilih kasih, terhadap keluarga masing-masing. Cara memberi daun pacci kepada calon mempelai adalah sebagai berikut.

a. Calon mempelai yang telah dirias sebagaimana layaknya pengantin didudukan di atas lamming (pelaminan) dan didampingi oleh seorang indo'botting (juru rias pengantin), di depannya diletakkan bantal yang dilapisi daun sirih. Kedua tangannya diletakkan di atas bantal dan daun sirih tersebut. Hal ini dimaksudkan agar dapat menerima daun pacci yang akan diberikan oleh orang-orang yang akan melakukan mappaci.

b. Diambil sedikit daun pacci yang telah dihaluskan, lalu diletakkan ke tangan calon mempelai. Pertama ke telapak tangan kanan, kemudian telapak tangan kiri, kemudian di jidat, lalu disertai dengan doa semoga calon mempelai kelak dapat hidup dengan bahagia. 
c. Sesekali indo'botting ataupun mereka yang meletakkan pacci menghamburkan wenno atau butiran beras kepada calon mempelai sebenyak tiga kali disertai dengan doa. Agar calon mempelai dapat mekar berkembang serta murah rezeki dikemudian hari.

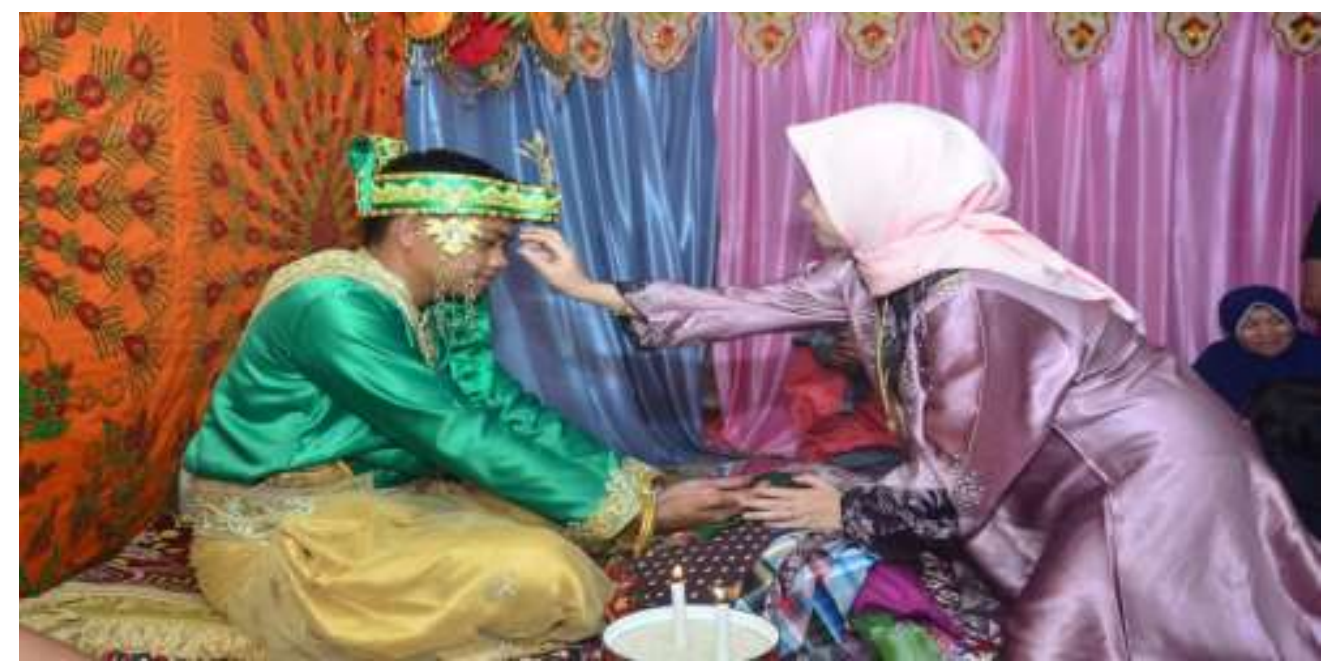

Gambar 4. Ritual mappacci

\section{Makna Ritual Upacara Mappacci}

1. Makna utamanya adalah kesucian hati calon mempelai menghadapi hari esok, memasuki bahtera rumah tangga, untuk melepas masa gadisnya masa remajanya (masa lajangnya) begitu pun dengan laki-lakinya.

2. Pacci, sebelum pewarnaan yang ditempelkan di kuku atau telapak tangan, maka pacci tersebut berubah menjadi warna merah pada kuku dan sangat sukar/sulit untuk menghilangkannya. Pewarnaan kuku suatu yang melambangkan harapan, yang memaknai semoga pernikahan nanti akan berlangsung dengan langgeng (selamanya) menyatu antara keduanya, serta kekal bahagia seumur hidupnya.

3. Malam mappacci ini merupakan acara hidmat, penuh doa, dan restu dari para keluarga dan undangan calon mempelai. Semoga doa restu para keluarga dan undangan dapat mengukir kebahagiaan kedua pasangan suami istri kelak dalam membina rumah tangga yang sakinah, mawaddah, dan warahmah. Rumah tangga yang bahagia penuh rasa cinta kasih sayang, sebagaimana sabda Nabi Muhammad saw "baetti jannati” yang artinya rumahku adalah surgaku.

4. Di dalam pelaksanaan upacara ritual mappacci akan melibatkan pasangan tujuh atau sembilan pasang. Dalam bahasa Bugis pitu atau duakkaserra yang maksudnya sembilan orang dari keluarga ayah, sudah termasuk ayah sendiri dan sembilan dari keluarga ibu sudah termasuk ibu sendiri. Satu persatu mereka dimintai mengambil sedikit daun pacci yang telah dihaluskan dan diletakkan di telapak tangan calon mempelai perempuan maupun calon mempelai laki-laki, tentu dengan disertai dengan doa dan restu untuk calon pengantin. Keluarga dan tamu yang diminta untuk meletakkan pacci adalah orang-orang yang mempunyai kedudukan sosial yang baik dan mempunyai kehidupan rumah tangga yang bahagia. Semua ini mengandung makna agar calon mempelai kelak di kemudian hari dapat hidup bahagia seperti mereka yang meletakkan pacci di atas tangannya. 


\section{Simpulan}

Ritual upacara mappacci diartikan sebagai bersih dan suci, yang bertujuan membersihkan jiwa dan raga calon mempelai sebelum mengarungi bahtera rumah tangga. Inti dari upacara prosesi mappacci adalah pemberian daun pacci (daun pacar) oleh keluarga yang telah ditetapkan. Satu persatu mereka dimintai mengambil sedikit daun pacci yang telah dihaluskan dan diletakkan di telapak tangan calon mempelai perempuan maupun calon mempelai laki-laki tapi tentunya pelaksanaannya terpisah. Keluarga dan tamu yang diminta untuk meletakkan pacci adalah orang-orang yang mempunyai kedudukan sosial yang baik dan mempunyai kehidupan rumah tangga yang bahagia. Semua ini mengandung makna agar calon mempelai kelak di kemudian hari dapat hidup bahagia seperti mereka yang meletakkan pacci di atas tangannya.

\section{Ucapan Terima Kasih}

\section{Daftar Pustaka}

Hoed, Benny H. (2008). Semiotik dan dinamika Sosial Budaya. Depok: Komunitas Bambu.

Indarwati, Nur Fadny Yuliani, \& Lina Mariana. (2020). "Ritual Mattompang Arajang, Prosesi Penyucian Benda Pusaka Kerajaan Bone: Tinjauan Semiotik Budaya”. Jurnal Onoma: Pendidikan, Bahasa, Dan Sastra. https://doi.org/10.30605/onoma.v6i2.388

Kridalaksana, Harimurti. (1993). Kamus Linguistik. Jakarta: PT Gramedia Pustaka Utama.

Mattulada (1985). "Latoa: Satu Lukisan Analitis Terhadap Antropologi-Politik". Makassar: LEPHAS.

Nasution. (2016). Metode Research (Penelitian Ilmiah). Cetakan ke-15. Jakarta: Bumi Aksara.

Budi Setyaningrum, N. D. (2018). BUDAYA LOKAL DI ERA GLOBAL. Ekspresi Seni. https://doi.org/10.26887/ekse.v20i2.392

Indarwati, Nur Fadny Yuliani, \& Lina Mariana. (2020). Ritual Mattompang Arajang, Prosesi Penyucian Benda Pusaka Kerajaan Bone: Tinjauan Semiotik Budaya. Jurnal Onoma: Pendidikan, Bahasa, Dan Sastra. https://doi.org/10.30605/onoma.v6i2.388

Manafe, Y. D. (2011). Komunikasi Ritual pada Budaya Bertani Atoni Pah Meto di TimorNusa Tenggara Timur. Jurnal ASPIKOM. https://doi.org/10.24329/aspikom.v1i3.26

Nur, E., \& Pala, R. (2020). MAPPACCI SEBAGAI MEDIA PESAN MASYARAKAT DI KABUPATEN BONE. Walasuji : Jurnal Sejarah Dan Budaya. https://doi.org/10.36869/wjsb.v11i2.160

Sarpinah, Salimin, A. S. P. (2018). Nilai-Nilai Yang Terkandung Dalam Budaya Mappacci Pada Rangkaian Pelaksanaan Perkawinan Orang Bugis. SELAMI IPS.

Sugiyono. (2019). Metode Penelitian Kuantitatif, Kualitatif, dan R\&D. Edisi I, Cetakan ke-2. Bandung: Alfabeta.

Teeuw, A. (1984). Khasanah Sastra Indonesia. Jakarta: Balai Pustaka. 